\title{
Formal Shifts Use on Achieving Pragmatic Equivalence in English - Indonesian Translation of KungFu Panda
}

\author{
Syifa'ul Lathifah $^{1 凶}$, Januarius Mujiyanto ${ }^{2}$ \\ 1. SMKN Jayakerta Kabupaten Karawang, Jawa Barat, Indonesia \\ 2. Universitas Negeri Semarang, Indonesia
}

\begin{abstract}
Article Info
Abstract

Article History:

Recived 28 July 2021

Accepted 28

September2021

Published 23

December 2021

This study is concerned with the analysis of Catford's formal shifts use in speech act translation from English into Bahasa Indonesia in Kung Fu Panda movie. The analysis covers the use of level shift and category shift on achieving pragmatic equivalence and how the visual-verbal relation happened along with the pragmatic achievement process. This study took documentation and a questionnaire on collecting the data. In this study, a theory from Baker (1992) was applied to analyze pragmatic equivalence achievement. Moreover, the

Keywords: pragmatic equivalence, shift, visual verbal relation. theory from Halliday (1994) in Martinec and Salway (2005) was used to identify visual-verbal relations. The results of the study depicted (1) the use of level shift and category shift were very needed which led to pragmatic equivalence achievement $(95,3 \%)$. Based on the target readers and expert raters, (2) the visual-verbal relation helped the translator on target text arrangement by providing the context of which the speech act was being uttered. The visualverbal relation identified in the Kung Fu Panda movie were exposition (12,7\%), enhancement (9,3\%), extension (5,3\%) and locution relation (72,7\%). (3) The translator tended to use category shift dominantly $(66,67 \%)$ for recreating the most suitable target text that was similar to the source text's pragmatic meaning.The large identification of visual-verbal relation locutionallowed target and expert readers to perceive the meaning lied in speech act only from the word given.
\end{abstract}

\footnotetext{
\Correspondence Address:

Jalan Raya Jayamakmur, desa Jayamakmur, Kec. Jayakerta,

Indonesia,

p-ISSN 2087-0108

E-mail: syifaullathif69@gmail.com

e-ISSN 2502-4566
} 


\section{INTRODUCTION}

As a product of culture, a language represents someone's thinking process. Understandably, people who use different languages in communication tend to find a problem when they are going to understand messages lied in a different language as they have dissimilar perspectives. Such a situation also applies to films. Therefore, a translator, someone who can bridge the cultural gap in such human interaction is very needed.

Due to different linguistic systems and forms, the translator will do some changes to restructure the target text meaning as close as possible to those meaning lied in the source text so that the pragmatic equivalence can be achieved. As a result, formal shifts are phenomena that cannot be avoided. When it comes to film, moreover, the relation between moving image and subtitle as the target text cannot be ignored. In subtitle making, there will be time and spatial constraints. Therefore, the translator should consider the relationship between the moving image as a visual model and the target text as a verbal model.

The translation is "a written text rendering process from a source language into a target language (Hatim \& Munday, 2004, p.6)". In this case, translation is viewed from its making process rather than a final product. Subtitling, one of the translation products, is "the act of writing down the actors' dialogues and nonverbal acts, or soundtrack at the bottom of the screen which comes along with the visual image (Diaz-Cintas, 2013, p.274)". During the translation process, formal shifts are inevitable. The changes that happen during the translation process which deal to form are called formal shifts (Catford, 1965 cited in Munday, 2004, p.76).

There are two main formal shifts used in translation product, level shift, and category shift. A Level shift is the changes that happen from the grammatical level to the lexical level. Category shift is closely related to the different language systems in both languages. This kind of shift represents a change in terms of the target text language category that holds the same function as those which are in the source text language system. Afterward, category shift involves several shifts such as "structure shift, unit shift, intrasystem shift, and class shift (Catford, 1965 cited in Munday, 2004, p.76)". Structure shift is the changing word sequence in a sentence. A unit shift is the changes of rank in a grammatical category from a source language into a different rank of the target text grammatical category. Intra-system shift shows the change during the translating process by using non-parallel terms though both source and target text have almost fit in the language system. Class shift refers to the changes that happen as the equivalent of source text item can be found at a different class of target text item.

A few studies related to translation equivalence were conducted by Luong (2016); Yuliasri (2016); Sutopo et al. (2017); Yuliasri and Hartono (2014); Mujiyanto (2011). Based on their studies, it can be inferred that the final purpose for the translator is to get meaning equivalence in his translated product.

Translation equivalence should be carried out from different aspects including the pragmatic aspect. Pragmatic equivalence is "a translation equivalence that is related to what extent a language is used communicatively and its translation is always being engaged with a context, so it can make sense (Baker, 2018, p.235)". Two major areas relate to pragmatic equivalence, namely "coherence, and implicature (Baker, 2018, p.235)". Coherence is an organizing system that creates a text. A text is called coherence when it is suitable to the reader's expectation. A coherence text will make the readers accept the information in the story as a thing that makes sense. Besides coherence, implicature is "also the area that connects to pragmatic equivalence. It concerns on speakers' meaning than each word's denotation meaning (Grice, 1975 cited in Baker, 1992, p.223)". A speaker can express his or her implicature either directly or indirectly.

In making meaning, the visual-verbal relation in this study will be the relation that happens within the combination of moving images and verbal language displayed on the bottom screen. According to Halliday (1994) cited in Martinec (2005), some relations that may 
happen between verbal mode and visual mode are extension, exposition, exemplification, enhancement, locution, and idea.

This study is concerned with English Indonesian translation of Kung Fu Panda movie. This study attempts to present how pragmatic equivalence is achieved through translation shifts in its subtitle and to what extent the pragmatic equivalent achievement relates to the visualverbal relation as well. The pragmatic equivalent achievement was evaluated by expert readers and target readers.

\section{METHODS}

This study implemented a descriptive qualitative design to analyze formal shifts use on achieving pragmatic equivalence. Documentation and questionnaire were used to gather the data. This study is concerned with the English - Indonesian translation of speech act in Kung Fu Panda. Furthermore, this study also focused on the analysis of formal shift types which were used in speech act translation according to Catford's (1965) theory. To analyze pragmatic equivalence achievement, we used a questionnaire that was adapted to Baker's (1992) theory. Then, the data rating was carried out by 15 target raters and 2 expert raters. Besides, the theory from Halliday (1994) in Martinec and Salway (2005) was used to identify visual-verbal relation within the speech act translations.

\section{RESULTS AND DISCUSSIONS}

Following analyzing the Kung Fu Panda movie and its English - Indonesian translation, some speech acts in the movie experienced different formal shifts. The analysis of formal shift types was based on Catford's (1965) theory. Regarding the data, the formal shifts identified were level shift and category shift. Table 1 depicts the formal shifts found in the translation.
Table 1. Types of Formal Shift

\begin{tabular}{llll}
\hline No & Type of Formal Shift & Frequency & Percentage \\
\hline 1. & Level Shift & 50 & 33.33 \\
2. & Category Shift & 100 & 66.67 \\
\hline & Total data & 150 & 100 \\
\hline
\end{tabular}

Regarding Table 1, it was noticeable 150 utterances that contained speech act experience formal shifts. Out of 150 utterances, 50 level shifts were manifested. Meanwhile, 100 utterances experienced category shifts. This was an example of a level shift.

ST: We'll bring you back a souvenir. (d. 3A)

TT: Kami akan kembali dan membawakan kau suvenir.(d.3B)

The structure of will bring back in (d. 3A) expressed simple future by using the grammatical structure will $+\mathrm{V} 0$. Then, the simple future in $(\mathrm{d}$. 3A) was shifted into the words "akan kembali membawakan". Regarding the Great Dictionary of the Indonesian Language (2016), the word akan belongs to an adverb. Meanwhile, the word kembali belongs to the intransitive verb and the word membawakan belongs to a transitive verb. It could be inferred that the sample experienced a level shift from grammar to lexis.

Moreover, the following was the example of a category shift identified in the Kung Fu Panda movie.

ST: Master Tigress! Face Iron Ox and his Blades of Death. (d. 73A)

TT: Guru Macan! Hadapi Sapi Baja dengan Pedang Kematiannya. (d. 73B)

It was observable that there was a change of structure in (d. $73 \mathrm{~A}, \mathrm{~d}$. 73B) and (d. 132A, d. 132B). The phrase of Iron Ox had proper noun + noun structure was translated into reverse arrangement Sapi Baja in which the structure was noun + proper noun in the target text.

\section{Level Shift on Achieving Pragmatic Equivalence}

A level shift happens when "a linguistic level of the source text is converted into another level in the target text (Catford, 1965 cited in Munday, 2004, p.76)". There are two kinds of level shifts. They are a shift from grammar to lexis and a shift from lexis to grammar. Lexis is the 
synonym of words. Table 2 presents the level shift use on achieving pragmatic equivalence in the Kung Fu Panda movie.

Table 2. Level Shift Use on Achieving Pragmatic Equivalence

\begin{tabular}{llll}
\hline & & & \\
No & Type of Level Shift & $\begin{array}{l}\text { Pragmatic } \\
\text { Equivalence }\end{array}$ & $\begin{array}{l}\text { Non } \\
\text { Pragmatic } \\
\text { Equivalence }\end{array}$ \\
\hline 1. & Grammar to lexis & 49 & 1 \\
2. & Lexis to grammar & 0 & 0 \\
\hline
\end{tabular}

Based on Table 2, it was visible that 50 utterances experienced a level shift within the translation process from English text into Indonesian subtitles. Specifically, these 50 utterances experienced a change from grammar to lexis. Here is the example of a translation that experienced a level shift and achieved pragmatic equivalence.

ST: The universe has brought us the Dragon Warrior! (d. $36 \mathrm{~A})$

TT:Alam raya telah menganugerahi kita Pendekar Naga! (d. 36 B)

The example above achieved pragmatic equivalence because both target and expert raters could identify well the pragmatic meaning delivered in the target text and it is similar to the source text's pragmatic meaning. Furthermore, the target text's meaning was natural, accurate, and clear according to target and expert readers. It means that the translation had coherence or it was suitable with the target rater's expectation. This fact was under the theory that revealed coherence as one of the major areas related to pragmatic equivalence (Baker, 2018, p. 235).

Moreover, 1 out of 49 utterances that undergo level shift did not achieve pragmatic equivalence.

ST: No, I'll bring me back a souvenir. (d.34A)

TT: Aku akan bawa sendiri. (d.34B)

It is considered as nonequivalent pragmatically. According to the expert raters and readers, it was not clear what kind of thing that the character would bring by himself. A souvenir as the vital information was deleted. As the result, the reader could not feel the same effect as the source text's implied meaning.

\section{Category Shift on Achieving Pragmatic Equivalence}

Besides level shift, category shift is also one of the formal changes that happen during a translation process. This kind of shift is subdivided into four types. Those were unit shift, structure shift, class shift, and intra-system shift (Catford, 1965). Table 3 displays the category shift use on achieving pragmatic equivalence in the Kung Fu Panda movie.

Table 3. Category Shift Use on Achieving Pragmatic Equivalence

\begin{tabular}{llll}
\hline No & Type of Category Shift & $\begin{array}{l}\text { Pragmatic } \\
\text { Equivalence }\end{array}$ & $\begin{array}{l}\text { Non } \\
\text { Pragmatic } \\
\text { Equivalence }\end{array}$ \\
\hline 1 & Unit & 36 & 3 \\
2 & Structure & 35 & 2 \\
3 & Class & 17 & 1 \\
4 & Intra-system & 6 & 0 \\
\hline
\end{tabular}

Referring Table 3, it was noticeable that 100 utterances experienced formal shifts with different category shifts. Out of 100 utterances, the unit shift happened 39 times. Next, 37 utterances experienced structure shift. Moreover, Class shift occurred 18 times and intra-system shift was used 6 times. The following is one of the speech act translations that experienced category shift and achieved pragmatic equivalence.

ST: Master Tigress! Face Iron Ox and his Blades of Death. (d. 73A)

TT : Guru Macan! Hadapi Sapi Baja dengan Pedang Kematiannya. (d. 73B)

The datum above was considered equivalent pragmatically since the target text meaning was accurate, natural, and clear. Moreover, regarding target and expert raters, the datum has coherence and the implicature was similar to the source text's pragmatic meaning.

There were 94 utterances with category shift that were considered equivalent pragmatically. Meanwhile, 6 utterances could not achieve pragmatic equivalence. The following example is considered non-pragmatic equivalent. ST: Trust me, it will. (D. 99A)

TT :Nanti. (D. 99B)

The target text was considered nonequivalent pragmatically. According to expert 
raters and readers, there was a meaning loss that disturbed the text cohesiveness. The translator not only did drastic changes from sentence level into word level but also chose inappropriate words. The word given as the target text is out of context so that the target and expert readers could not catch the restructured message of the source text well. Consequently, the readers and expert raters could not feel the same effect as the source text's implied meaning.Visual Verbal Relation on Achieving Pragmatic Equivalence In the case of pragmatic equivalence of speech act translation, the role of the visual image in assisting the translator to produce target text could not be taken for granted. Speech acts could be delivered well in the context of a conversation.

In the Kung Fu Panda movie, the visual image provided the context of the speech act. The visual-verbal relation found in translation were exposition, exemplification, enhancement, extension, and locution. Table 4 presents different types of visual-verbal relation which were identified in the Kung Fu Panda movie.

Table 4. Type of Visual Verbal Relation

\begin{tabular}{|c|c|c|c|c|c|c|}
\hline $\begin{array}{l}\text { Type } \\
\text { of } \\
\text { Visual }\end{array}$ & \multicolumn{4}{|c|}{ Expansion } & \multicolumn{2}{|c|}{ Projection } \\
\hline $\begin{array}{l}1 \\
\text { Relati } \\
\text { on }\end{array}$ & $\begin{array}{l}\text { Expos } \\
\text { ition }\end{array}$ & $\begin{array}{l}\text { Exemplif } \\
\text { ication }\end{array}$ & $\begin{array}{l}\text { Enhanc } \\
\text { ement }\end{array}$ & $\begin{array}{l}\text { Exten } \\
\text { sion }\end{array}$ & $\begin{array}{l}\text { Locu } \\
\text { tion }\end{array}$ & $\begin{array}{l}\text { Id } \\
\text { ea }\end{array}$ \\
\hline $\begin{array}{l}\text { Frequ } \\
\text { ency }\end{array}$ & 19 & 0 & 14 & 8 & 109 & 0 \\
\hline $\begin{array}{l}\text { Perce } \\
\text { ntage }\end{array}$ & $\begin{array}{l}12.70 \\
\%\end{array}$ & $0 \%$ & $9.30 \%$ & $\begin{array}{l}5.30 \\
\%\end{array}$ & $\begin{array}{l}72.7 \\
0 \%\end{array}$ & $\begin{array}{l}0 \\
\%\end{array}$ \\
\hline
\end{tabular}

Based on Table 4, there was a significant difference between the proportions of Expansion and Projection (27.3\% and 72.7\%). Regarding Projection, Locution took vast proportions, with 109 occurrence frequency, while none of the Idea was accounted for. If the typical realization of Locution in comics was enclosed in the speech bubble, the Locution realization could be enclosed in the quoting of wording spoken by each character in the film. The illustration of Locution is confirmed in Figure 1.

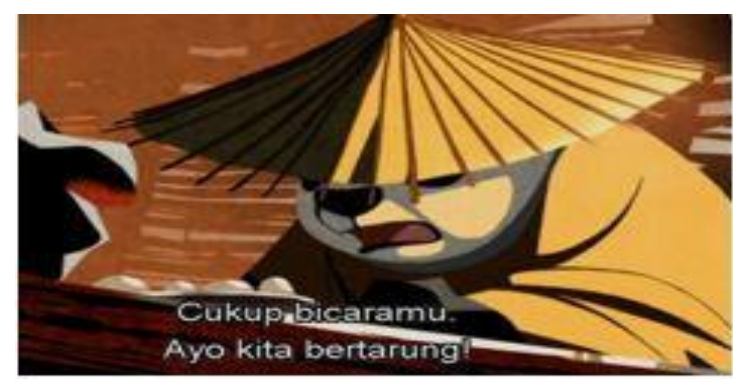

Figure 1. Projection of locution

The tons of locution $(72,7 \%)$ as visualverbal relations highlight the Kung $\mathrm{Fu}$ Panda movie. This situation meant that subtitle contains the actors' dialogues more than the nonverbal act. By sustaining the dialogues between actors, the story in Kung Fu Panda may move forward. Moreover, locution is the most identified visual-verbal relation in Kung $\mathrm{Fu}$ Panda. The large identification of this kind indicated that the verbal mode allowed target and expert readers to perceive the meaning lied in speech act only from the word given without knowing full context supported by visual mode when the characters uttered the speech act.

However, 7 speech act translations which were considered nonequivalent pragmatically in Kung Fu Panda had locution as the visualverbal relation. This fact was in line with Mujiyanto (2016) stating that when someone relied on verbal mode superior to the visual mode in delivering a message, the readers would catch the meaning implied only from the literal meaning of each word.

Regarding Expansion relations, Exposition, Enhancement, and Extension are more familiar than Exemplification. It means that those three modes are complementing to the relatively meaning of the Kung Fu Panda movie. The Exposition was in the first rank with $12.7 \%$. Enhancement and Extension followed on 9.3\%. The Extension came next with 5.3\%. However, none of the Exemplification was confirmed. The great amount of Exposition data in the film, exhibit that the visual mode and verbal mode were handled to strengthen and reformulated meanings rather than to exemplified or explained meanings.Figure 2 might perform an illustration for Exposition relation in the data. 


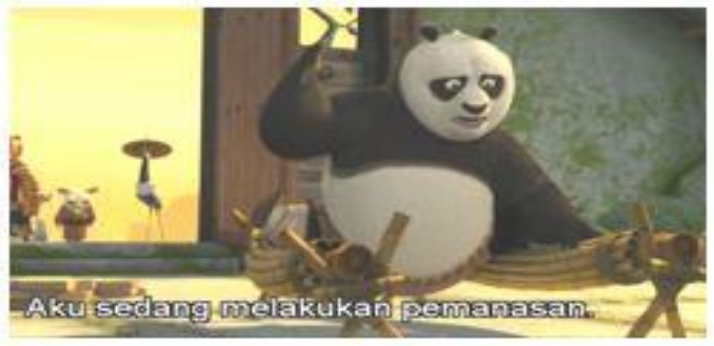

Figure 2. Exposition

The verbal mode in Figure 2 showed "Aku sedang melakukan pemanasan". Meanwhile, the visual mode depicts a Panda who did the splits between two bundles of bamboo which could be understood that he was doing a warm-up move. Both visual mode and verbal mode have concurrently restated and emphasized the meaning. Because a clear target text meaning has been delivered well, readers could feel that the target text's meaning was similar to the source text's. Figure 3 below might perform an illustration for Enhancement relation in the data.

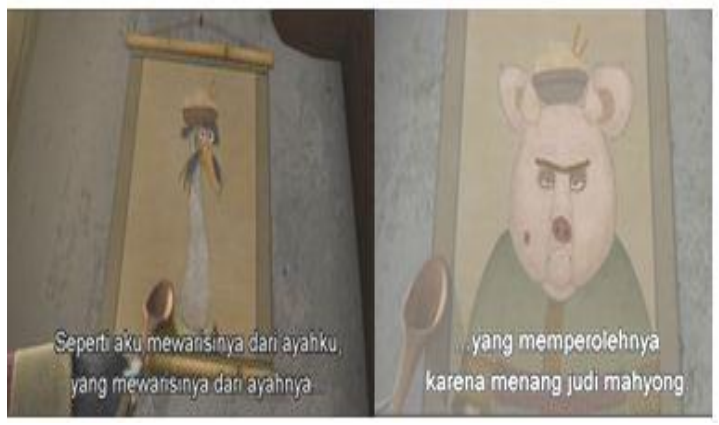

Figure 3. Text enhances image causually

Figure 3 was an illustration of causal Enhancement relation. The target text as the verbal mode presents "seperti aku mewarisinya dari ayahku, yang mewarisinya dari ayahnya yang memperolehnya karena menang judi mahyong". The visual mode displayed someone who pointed out different characters hanging on a wall restaurant which could be interpreted asformer restaurant owners in sequence. Besides, the verbal mode gave new information that enhanced the visual mode the cause why the character could take over the restaurant from the very first owner. Figure 4 depicted illustration for Exposition relation in the data.

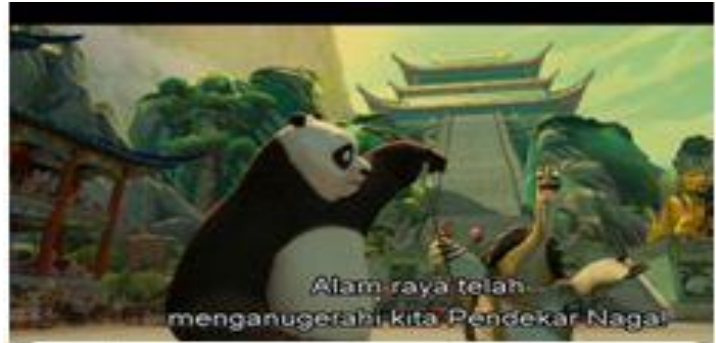

Figure 4. Image Extend text

In Figure 4, the target text as the verbal mode showed "Alam raya telah menganugerahi kita Pendekar Naga". Then, the visual mode extended the verbal mode by depicting not only a turtle that lifted the panda's hand in front of the audience but also gave hints or new information to the target readers about who the true Dragon Warrior is. This visual-verbal relation helped the translator in choosing the proper word before creating target text and the pragmatic meaning still could be delivered well.The relation that occurred between visual mode and verbal mode in Kung Fu Panda was in line with Unsworth's (2006) statement that the combination of image and language became the new way of meaningmaking. The fact that the translator considered visual-verbal relation before producing the most suitable target text proves that the visual-verbal relation could not be overlooked. The pragmatic equivalence could be achieved because it was closely related to the context. In Kung $F u$ $P a n d a$, the context was displayed through visualverbal relation, so that target and expert readers could feel the same feeling as the source text's pragmatic meaning.

\section{CONCLUSIONS}

After analyzing the data, there were two formal shifts manifested in the Kung Fu Panda movie. The category shift was considered as the most widely used by the translator of the subtitle. Regarding the analysis, it could be inferred that the use of formal shifts on achieving pragmatic equivalence was essential. By experiencing formal shifts, the translator could create the target text that had a natural and accurate translation. The target text's pragmatic 
meaning is clear as well. Moreover, visual-verbal relation also supported the translator to produce the most suitable target text by providing the context of the utterance in a movie. Consequently, the target text that experienced formal shifts also had coherence. The target text was considered to make sense since it synchronized with the scenes or visual modes depicted. Besides, Locution was the prominent visual-verbal relation identified in the Kung $\mathrm{Fu}$ Panda movie. The fact that the translator considers visual-verbal relation before producing the most suitable target text proves that the visual verbal relation cannot be overlooked. The pragmatic equivalence can be achieved because there is a syncronization between the target text and every scenes in the movie.

In Kung Fu Panda, the context is displayed through visual verbal relation, so that target and expert readers can feel the same feeling as the source text's. In Kung Fu Panda, the context is displayed through visual verbal relation, so that target and expert readers can feel the same feeling as the source texts'.

However, the non pragmatic equivalence is mostly identified in locution relation when the translator wrong choice of diction results the target text as the verbal mode that does not relate with the visual mode at all. Consequently, the target readers get difficulty to catch the target text implied meaning. Therefore, in making meaning, visual verbal relation cannot be ignored.

For further research, it would be better if the research with the same lines were viewed from distinct viewpoints because this study only concerned with the formal shift used on achieving pragmatic equivalence in the movie. Hence, we suggested that further research could expose a formal shift on achieving other translation equivalence within other literary works or educational context.

\section{REFERENCES}

Ahdillah, M. Z. I., Hartono, R., \& Yuliasri, I. (2020). English-Indonesian translation of idiomatic expressions found in the Adventure of Tom Sawyer: Strategies used and resulted equivalence. English Education Journal, 10(4), 480-492.

Al Farisi, Z. (2015). Speech act of iltifat and its Indonesian translation problems. Indonesian Journal of Applied Linguistics, 4(2), 78-90.

Aliurridha, A., \& Setiawan, T. (2019). Shifts and equivalencies of idiomatic expressions in novel "The Name of Rose". Journal on English as a Foreign Language, 9(2), 163-180.

Aloojaha, A., Nababan, M. R., \& Djatmika, D. (2018). The impact of translation techniques on shifting meaning of ordering speech act. Lingua Cultura, 12(3), 279-287.

Altikriti, S. F. (2011). Speech Act Analysis to Short Stories. Journal of Language Teaching \& Research, 2(6).

Ariyaningsih, N. N. D., \& Santika, I. D. A. D. M. (2018). The translation of English tourism news text into Indonesian. Journal of Applied Studies in Language, 2(2), 151-157.

Baker, M. (2018). In other words: A coursebook on translation. Routledge.

Basthomi, Y., Hidayati, M., Zen, E. L. (2017). Indonesian Teachers' Directives in English Language Classrooms. KnE Social Sciences, 164-174.

Budiana, A. A., Rukmini, D., \&Sutopo, D.,. (2017). The use of translation techniques in subtitling the Dhaup Ageng documentary movie. English Education Journal, 7(1), 0105.

Carretero, M., Maíz-Arévalo, C., \& Martínez, M. Á. (2015). An analysis of expressive speech acts in online task-oriented interaction by university students. Procedia-Social and Behavioral Sciences, 173, 186-190.

Catford, J. C. (1965). A linguistic theory of translation. Oxford University Press.

Chen, Y., \& Wang, W. (2016). Relating visual images to subtitle translation in Finding Nemo: A multi-semiotic interplay. Translation \& Interpreting, 8(1), 69-85.

Cintas, J. D. (2013). Theory, practice and research. The Routledge handbook of translation studies, 273. 
Cintas, J., \& Ramael, A. (2014). Audiovisual Translation: Subtitling. New York: Routledge.

Dejica-Cartis, D., \&Simon, S. (2015). Speech acts in written advertisements: Identification, classification and analysis. Procedia-Social and Behavioral Sciences, 192, 234-239.

Fitriana, I. (2013). Translation Analysis of Directive Speech Acts in" Eat Pray Love" Novel and Its Translation into Indonesian. Prasasti: Journal of Linguistics, 2(2).

Hartono, R. (2014). Translation analysis on utterances Used in daily communication (A Pragmatic View Based on the English and Indonesian Cultural Perspectives). Arab World English Journal, 5(3).

Hartono, R., \&Rupiah, S. N.. (2017). Shift and equivalence of noun phrases in EnglishIndonesian translation of Barbie short stories. English Education Journal, 7(3), 227236.

Hatim, B., \& Munday, J. (2004). Translation: An advanced resource book. Psychology Press.

Kirkpatrick, R. (2012). English education in Thailand: 2012. Asian EFL Journal, 61, 2440.

Luong, V. N. (2016). Equivalence in the Vietnamese translation of Shakespeare's Romeo and Juliet. target, 4(01).

Martinec, R., \& Salway, A. (2005). A system for image-text relations in new (and old) media. Visual communication, 4(3), 337371.

Mestre-Mestre, E. M. (2015). The construction of meaning in the Second Language Classroom. A Multimodal discourse analysis. Procedia-Social and Behavioral Sciences, 173, 228-233.

Muhartoyo, M., \& Kristani, K. (2013). Directive Speech Act in The Movie "Sleeping Beauty". Humaniora, 4(2), 949-966.

Mujiyanto, Y. (2016). The dependence of verbal passages on visual representation in meaning-making. PROSIDING

PRASASTI, 884-890.

Nhat, T. N. M., \& Pha, N. T. M. (2019). Exploring Text-Image Relations in English Comics for Children: the Case of "Little Red Riding Hood". VNU Journal of Foreign Studies, 35(3).

Rojo López, A. M. (2002). Applying frame semantics to translation: A practical example. Meta: journal des traducteurs/Meta: Translators' Journal, 47(3), 312-350.

Searle, J. (1979). Expression and Meaning. Cambridge: Cambridge University Press.

Sultan, K. M. (2007). The semantics, pragmatics and translation of speech acts. journal of the college of basic education, 10(50).

Tomášková, R. (2017). "And this is the view from outside my window": On text and image interplay in university website blogs. Topics in Linguistics, 18(2), 81-93.

Unsworth, L. (2007). Image/text relations and intersemiosis: Towards multimodal text description for multiliteracies education. In Proceedings of the 33rd IFSC: International Systemic Functional Congress. Pontificia Universidade Catolica de Sao Paulo.

Vera, M. P. G. (2011). Translating images: the impact of the image on the translation of Disney's Alice in Wonderland into Spanish. Miscelánea: A journal of English and American studies, 43, 33-55.

Wijayanto, A. \& Yafi, M. A-.(2017). Illocutionary Acts in Movie Subtitling: the Accuracy of their Pragmatic Translation. URECOL Proceeding, 736-744.

$\mathrm{Wu}, \mathrm{S}$. (2014). A multimodal analysis of imagetext relations in picture books. Theory and Practice in Language Studies, 4(7), 1415.

Yule, G. (1996). Pragmatics. Oxford: Oxford University Press.

Yuliasri, I. (2016). Translation techniques and pragmatic equivalence in Indonesian translation of humorous utterences in the Walt Disney's Donald duck comics. Prosiding Prasasti, 409-414. 